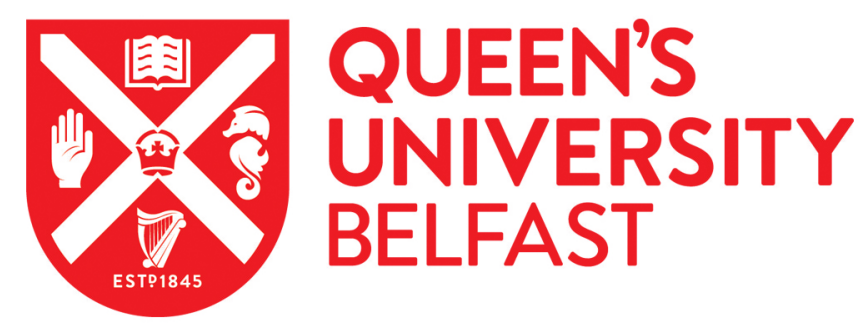

\title{
The case of Franca Viola: Debating Gender, Nation and Modernity in 1960s Italy
}

Cullen, N. (2016). The case of Franca Viola: Debating Gender, Nation and Modernity in 1960s Italy.

Contemporary European History, 25(1), 97-115. https://doi.org/10.1017/S0960777315000491

\section{Published in:}

Contemporary European History

\section{Document Version:}

Peer reviewed version

\section{Queen's University Belfast - Research Portal:}

Link to publication record in Queen's University Belfast Research Portal

\section{Publisher rights}

(C) 2016 Cambridge University Press.

This work is made available online in accordance with the publisher's policies. Please refer to any applicable terms of use of the publisher.

\section{General rights}

Copyright for the publications made accessible via the Queen's University Belfast Research Portal is retained by the author(s) and / or other copyright owners and it is a condition of accessing these publications that users recognise and abide by the legal requirements associated with these rights.

Take down policy

The Research Portal is Queen's institutional repository that provides access to Queen's research output. Every effort has been made to ensure that content in the Research Portal does not infringe any person's rights, or applicable UK laws. If you discover content in the Research Portal that you believe breaches copyright or violates any law, please contact openaccess@qub.ac.uk. 
Short title: The Case of Franca Viola

Title: The case of Franca Viola: Debating Gender, Nation and Modernity in 1960s Italy

Author: Niamh Cullen

\begin{abstract}
Seventeen year Sicilian Franca Viola was abducted and raped in 1965, with the intention of forcing her into marriage. She came to prominence in 1966 as the first Sicilian woman to refuse a so-called reparatory marriage - which would have legally absolved her rapist of his crime- resulting in his prosecution in a high profile trial in December 1966. Through an examination of the media coverage, and by making use of history of the emotions, this article examines the trial as a crucial moment for post-war Italy, when gender, sexuality and marriage were being redefined in a rapidly changing society. Different emotional styles could be connected to debates about national identity and regional character, as well as to broader anxieties about 'modernity' and 'backwardness'.
\end{abstract}

On 26 December 1965 seventeen year old Franca Viola was abducted from her home in the town of Alcamo in Western Sicily by a group of armed men led by her former fiancé, Filippo Melodia. ${ }^{1}$ (figure 1) Both her mother and younger brother were at home with her and Franca was not abducted without a struggle. When she was bundled into the getaway car Viola's mother Vita Ferro

\footnotetext{
I would like to acknowledge the support of the Irish Research Council, whose CARA/European Commission co-fund research fellowship scheme allowed me to carry out the research for this article. Department of History, University of Southampton, Avenue Campus, Highfield, Southampton S017 1BF ; niamhanncullen@gmail.com.
} 
was briefly dragged along with the vehicle and was left bleeding on the street. Franca's brother Mariano would not let go of her and was thus taken with her in the car, only to be returned to the outskirts of the village hours later. Franca herself was not found for a week, despite an immediate and extensive police search of the area. Her ordeal came to a dramatic end when police stormed the nearby home of Filippo Melodia's sister, where he had been hiding out with Viola. ${ }^{2}$ Melodia made one last desperate and defiant stand by attempting to flee onto the rooftops with Viola before he was taken into police custody.

The details of Franca Viola's abduction were at once both familiar and unusual to onlookers in 1960s Sicily. It was a somewhat recognised Sicilian practice to kidnap a young woman in order to force her into marriage. The logic of such kidnaps rested on the notion that a woman's honour was measured by her sexual chastity. Once her honour had been compromised by spending time alone with a man - although rape was common in such cases, sexual violence was considered of secondary importance to the loss of honour as a social value she could only repair it through marriage to her abductor. ${ }^{3}$ Since the loss of honour affected not just the woman but also her family, parents and siblings would typically also be invested in securing the marriage. The concept of 'reparatory marriage' - in which the crime of rape could be absolved through marriage - was present in the Italian legal code until $1981 .{ }^{4}$ However, such practices were more prevalent in rural Calabria and Sicily, the primary focus of this article.

Although the honour system was being challenged by migration, the rise of mass culture and the creeping urbanisation of Sicily itself, it still held real 
currency up until the 1960 s. ${ }^{5}$ Murder for the sake of honour - usually defined as the killing of a woman's lover by her husband, father or brother - was the more dramatic, violent and public face of honour crime. Such cases, although treated with greater leniency than other murder cases by the Italian legal system, generally did go to court. This notion of honour crime was so familiar to the public that it is strongly suspected that many Sicilian honour killings were in fact passed off as such by the mafia to receive shorter sentences. ${ }^{6}$ Abduction with the aim of forced marriage was, by contrast, usually a more private affair, resolved between families rather than by the law. During the same weeks as Franca Viola's abduction the Sicilian daily Giornale di Sicilia carried details of several other abductions of young women. ${ }^{7}$ They always ended with charges being dropped and the promise of marriage. The vast majority of such cases likely never even made it to the newspapers.

The honour system also necessitated strict control of women's movements, and since unmarried women in rural Sicily typically had little opportunity to meet men in public and to choose a marriage partner by themselves, couples often took the drastic step of elopement - known as a fuitina - in order to secure a love marriage. ${ }^{8}$ Steps might also be taken to make an elopement appear like a abduction in order to preserve the woman's reputation. It was thus often difficult to tell whether the incident in question was a violent abduction or the desperate, romantic gesture of a couple in love. It was this ambiguity between love, coercion and violence that lay at the heart of the 'fuitina', which Melodia and his accomplices doubtless hoped to exploit with their actions. They also acted under the assumption that family and community 
would demand a marriage between the two, thus bringing the case to a familiar close.

The case was also in many respects quite unusual from the beginning, and several crucial details served to lift it out of the domain of the familial, private and local and into the public, national sphere of media and courtroom. The level of violence used in Viola's kidnap appeared excessive by the standards of most abductions for the scope of marriage. Generally abductions happened in public spaces; by the logic of the honour system, which dictated that modest women should keep to the domestic sphere, it could be argued that they had somehow colluded in their abduction. ${ }^{9}$ Franca Viola, however, was forcibly taken from her home, in the presence of her mother and brother. The fact that the kidnappers had carried arms and fired warning shots in front of family and neighbours also pointed to the fact that this was no ordinary 'fuitina', in which the boundaries between love and coercion could not easily be drawn. It was quite clearly a violent crime. Even in the interior of Western Sicily, where the tolerance of violence in ordinary life was higher due to the presence of the mafia, Viola's kidnap had crossed the boundary of what was acceptable. ${ }^{10}$

While such kidnaps often reached the local pages of the Sicilian newspapers, the Viola kidnapping made the front headlines of both Sicilian dailies and, unlike most other cases, was widely reported in the major Italian newspapers. ${ }^{11}$ Both the length of Viola's incarceration and the nature of its conclusion were also noteworthy; most abductions ended within a couple of days at most, with the return of the couple to the young woman's parents and the promise of a marriage that all parties would now agree upon. Viola however was 
only (?) freed after seven days by a police raid, and Melodia was taken into immediate custody.

From the beginning, it was also clear that this was no 'ordinary' elopement or abduction. There were hints of mafia involvement early on, but, in addition, the Viola family refused to play the part assigned to them in this familiar family drama. Instead of negotiating with the abductors to settle the matter privately, they had immediately turned to the law. However, even at this point it was not clear that the case would become the national event that it did. It was Franca Viola's decision, strongly supported by her father Bernardo Viola, to refuse the reparatory marriage that was offered, which then necessitated the prosecution of Filippo Melodia and his accomplices in a high profile trial the following December, that ultimately marked this case out as a watershed event in the history of modern Italian marriage, sexual and gender politics. While Viola's ordeal is mentioned in many social and gender histories of the period, it has not yet been examined in any detail by historians. ${ }^{12}$ This article aims to redress this gap, placing the case in the context of a society in rapid transition, and, through examining media coverage of the abduction and subsequent trial, demonstrating how it ignited national discussions about regional differences, the position of women in a changing society and the meaning of modernity.

The trial raised many questions regarding family, marriage and love itself, as well as the nature of Italian masculinity. It also provoked debate about the rate at which society was changing and the regional dimensions of this transition. Italy had undergone rapid and profound change in the preceding decade, transformed by an strong industrial boom in the northern cities from a poor, rural nation recovering from war into a prosperous, proud and self- 
consciously modern society. ${ }^{13}$ When public opinion was drawn to the southern peripheries of the nation by the 1966 trial, it stirred anxieties and provoked questions not only about love, sexuality and gender politics, but also about how Italy should define itself as a nation. What emotional styles were acceptable within the nation and was Italy 'modern' and European or southern and 'traditional'?14 What was the place of Sicily within the new nation emerging by means of the economic miracle, and could regional differences be tolerated or did they have to be flattened out?

This was not the first time that an Italian murder case had magnified tensions between competing emotional styles and masculinities, reflecting anxieties about how Italy should define itself as a nation. In 1879 the murder of army captain Giovanni Fadda by his wife's lover had provoked similar concerns. ${ }^{15}$ The restrained and respectable masculinity of Fadda was contrasted with the brash and passionate style of his murderer Pietro Cardinali and with his wife's roots in Calabria, where, in the words of the state prosecutor, 'the passions were more alive'. ${ }^{16}$ The civilised, modern, bourgeois heart of the newly unified nation was perceived to be under threat from those at its passionate and untamed peripheries. In 1966 the nation was yet again seeking to define itself not just as unified, but as prosperous, modern and European. The media coverage of the Viola case thus carried at its core a long running debate about national identity, southern 'difference' and the very meaning of modernity for Italian society.

The post-war economic miracle and the rediscovery of the 'southern question' 
Italy at the end of the Second World War was a nation in ruins: poor, largely rural, with much of its infrastructure destroyed - and deeply divided. Development had historically been uneven across the peninsula, with industrial development concentrated in the northern cities while the southern provinces were typically less economically developed - a pattern which was perpetuated in the post-war period. ${ }^{17}$ From the late 1950 s onwards Italy was to undergo dramatic and lasting social changes as the economic boom of the northern industrial cities of Milan, Turin and Genoa began to take off. While in 1950 Italy's per capita earnings had been among the lowest in Europe, this figure had tripled by 1973 , bringing Italy very close to the European average. ${ }^{18}$ These unprecedented levels of economic growth heralded a social, cultural and consumer revolution. ${ }^{19}$ The position of women in Italian society was also beginning to change; the traditional assumption that urbanisation contributed to the rise of the housewife and the decreased female participation in the workforce has been challenged by the work of Anna Badino. ${ }^{20}$ The numbers of women in secondary school education were also growing rapidly, starting in the 1950s and accelerating following the 1962 education reforms, contributing to a substantial increase in women university students in the $1960 \mathrm{~s}^{21}$ A 1960 sociological study of the aspirations of young Italians living in and around Milan revealed that women no longer saw their future as bound up solely in marriage; a career was also a possibility, particularly for those from urban backgrounds where opportunities were greater. ${ }^{22}$ Customs regarding sexuality and courtship were also adapting to the new industrial society; family size was on the decline in the 1960s, while divorce became a matter of urgent public discussion in the 1960s leading to its legalisation in $1970 .^{23}$ 
Because industrial development was concentrated in the north, one of the principal ways in which those from the southern provinces participated in the economic miracle was through migration. Paul Ginsborg and Guido Crainz place the numbers involved in inter-regional migration from 1955 to 1970 between nine and ten million. ${ }^{24}$ While migration within regions was also common, particularly in Lombardy and Piedmont, population movement from south to north was certainly striking. The influx of migrants was particularly noteworthy in Milan and Turin. Franco Alasia and Danilo Montaldi's classic study of migration to Milan, first published in 1960, found that the number of migrants from the south of Italy, Sicily and Sardinia to Milan had almost tripled between 1955 and 1958, and was set to increase further in the following decade. ${ }^{25}$ The population of Turin also expanded from approximately 700,000 to 1,170,000 between 1951 and 1969, with a large proportion of these new inhabitants of southern origin. ${ }^{26}$

By the mid 1960s Italy had been largely transformed into an affluent, consumerist and self-confident society, in which opportunities for women were expanding. However, regional inequalities persisted and the influx of migrants from the southern provinces to the northern cities from the late 1950s onwards was a constant daily reminder of both structural inequalities and cultural difference within the nation. ${ }^{27}$ In his classic study of southern migration to Turin, Goffredo Fofi detailed the definite cultural differences that the Piedmontese perceived between themselves and the migrant communities. In his interviews with Turin factory employees about their perceptions of their southern coworkers, one of the recurring themes was how they "behaved "barbarically" 
towards their wives and treated women badly in general'.28 The wives of migrants from the southern regions were generally found by Fofi to seldom leave their homes; however, in his interviews with their husbands, it was always stressed that the women had complete freedom. Fofi put their defensive responses - which did not seem to reflect reality - down to the men's awareness of northern stereotypes of southern men as 'barbaric' and 'retrograde' towards women. ${ }^{29}$

Honour crime in particular was highlighted as a dramatic reminder of the cultural differences between northern and southern Italians, for the Piedmontese. However, when polled, there were marked regional differences in the attitudes of southern men towards such crimes; those from Calabria, Sicily and Sardinia were much more likely to tolerate the notion of honour crime than those from other southern regions. ${ }^{30}$ Those from the southernmost tip of Italy and from its islands were thus perhaps the most alien to the sensibilities of selfconsciously modern and progressive northern Italy, and migration was bringing both groups into much closer contact than before. When the kidnap of Franca Viola brought these issues to the fore, media debates were to reflect anxieties about regional character and national identity and questions concerning what kind of behaviour could be considered modern, Italian and therefore acceptable and what lay outside the imagined boundaries of the nation.

The south, however, had already had a strong place within the intellectual and popular consciousness before the migration waves of the 1950s and 1960s. The civic-minded left-wing consciousness raised by the antifascist resistance, together with the land struggles of the rural south in the late 1940s, had already brought renewed attention to the area, from Carlo Levi's literary memoir of 
internal exile in 1930s Basilicata to Ernesto De Martino's ethnological work on folk cultures and magic in southern Italy and Rocco Scotellaro's posthumously published study of politics and community in rural Basilicata. ${ }^{31}$ Meanwhile, after 1945, anthropologists from the Anglophone world were turning their attentions from tribes to peasants, examining marginal experiences in rural Europe. While the work of Frederick Friedmann exposed and improved the desperate conditions of the poorest inhabitants of Matera, in Basilicata, there was also a more ambiguous Cold War strain to much of this work. ${ }^{32}$ Edward Banfield's The Moral Basis of a Backward Society attempted to explain why rural Basilicata had not followed a typical modernisation path, rather than to understand it on its own terms. ${ }^{33}$ Now criticised as a crude application of Cold War modernisation theory, it was influential on post-war Italian policy towards the south. Although debates about southern difference and development had been on-going in some form since Italian unification in 1861, the post-war period saw a definite reawakening of interest in the Italian south, inspired by both the civic activism of the antifascist resistance and by Cold War concerns about modernisation. ${ }^{34}$

Although second-wave feminism did not take off until the early 1970s, in the 1960s there was also increased attention to the changing place of women in Italian society in radio, television and print media. ${ }^{35}$ Television inquiries tackled the issue of women and work, bringing to the fore the traditional cultural restrictions on southern women working, as well as honour crime. ${ }^{36}$ The new illustrated weeklies of the post-war era also used both photography and reportage to bring such issues to a wider national reading public - Epoca, for example, published a multi-page feature on women, work and sexuality in Lucania in 1964, while Pasolini's 1965 documentary film Comizi d'amore also 
probed attitudes towards gender and sexuality in Sicily and Calabria. ${ }^{37}$ The renewed focus on the south therefore also highlighted regional attitudes to gender, now perceived to be sharply out of step with the modern nation. Perceptions of southern cultural difference were thus brought into sharper focus with the rise of the mass media; discussions which had once taken place between intellectuals were now spilling out into the sphere of mass culture. It is in this context that the ordeal of Viola and the subsequent trial of Filippo Melodia should be understood.

Sicily, of course, was the most exotic, intriguing and feared part of Italy's mezzogiorno; the southern tip of the 'south' and associated above all in the 1960s with the mafia, poverty and honour crime. Activist and writer Danilo Dolci was one of the first to bring real attention to Sicily, with his 1956 study of urban poverty in Palermo. ${ }^{38}$ The publication of an English translation in 1959, with an introduction by Aldous Huxley, illustrated the growing international interest in Sicily. ${ }^{39}$

By the 1960s the position of women in Sicilian society was also receiving growing attention both nationally and internationally. Lieta Harrison, born in Sicily to British-American parents, was a student in Palermo in her twenties when she published her inquiry into the plight of Sicily's 'dishonoured' women. ${ }^{40}$ Published with an introduction by Pasolini and garnering the attention of Fellini among others, the book had a notable success in Italy. ${ }^{41}$ While Harrison's intention was to expose the lowly position and harsh treatment of women in Sicilian society, the tone of the book was somewhat sensationalist. Published in 1966, the same year as the Filippo Melodia trial, the English translation promised that this 'searing study of the humiliation of women in modern Sicily .. 
. must make anyone ... shudder with disgust at the humiliations and cruelty' of Sicilian society. ${ }^{42}$ In Britain, as in much of Europe and indeed Italy, the 1960s were bringing about a social and sexual revolution. Harrison's exposé of the plight of Sicilian women must have posed a stark and dramatic contrast to the world of its readers, whether in northern Italy or in Britain. The aim it seems, certainly in the international marketing of the book, was to provoke horror rather than understanding, sharpening the perception of difference between 'modern' Europe and those on its southern peripheries who were regarded as backward and unchanging.

In popular culture too, Sicilian difference was garnering both dramatic and comic attention, particularly in the work of film director Pietro Germi. Born in Genoa, Germi, like many others at the time, became interested in the problems and differences of Sicilian society. Based on the 1960 novel 'An Honour Crime', his 1961 film Divorce, Italian Style won international acclaim for its comic exposition of Italian family law. Germi's villain Don Cefalù proved that because of the clemency with which honour crime was treated under Italian law, it was easier for a man to kill his wife than to obtain a divorce, illegal in Italy until 1970.43 While the novel on which the film is based was set in and around Naples, it is significant that Germi moved the action to Sicily, the region by then most closely associated with honour crime in Italy. His follow up film, Seduced and Abandoned, although billed once again as a comedy, was intended as a deeper study of Sicilian mores regarding gender, sexuality and marriage. It examined the plight of fifteen-year-old Agnese, who was raped and made pregnant by her sister's fiancé Peppino. Her blustering father attempted to repair the family 
honour first through the attempted murder of Peppino and finally by forcing Peppino and Agnese to marry following a staged abduction. The reception of the film in Italy again revealed both concern for southern issues and the lack of consensus about how to depict them; critical attention was divided between those who saw Germi's film as a serious commentary on the matters of honour and gender politics in the south and those who accused him of a lack of understanding which spilled over into 'racism, Italian style'. ${ }^{44}$ The colourful presence of Sicily on screen, as well as the growing visibility of southern migrants in the northern industrial cities was, by 1966, a continued reminder to Italians of cultural and social difference within their nation, whether it was perceived as menacing or in need of understanding. However, there was no clear consensus on how to represent such issues, or of their place within the modernising nation.

\section{Love and masculinity on trial in Trapani, December 1966}

The trial of Filippo Melodia and his accomplices began on 9 December 1966 and lasted for nine days, resulting in an eleven-year prison sentence for Melodia. It brought the national media to Trapani, a small port city at the westernmost tip of Sicily and Alcamo's provincial capital. A year earlier in Catania, the trial of Gaetano Furnari for the murder of his daughter's lover had provoked great consternation in political and legal circles. Sentenced to less than three years in prison because his was considered a crime of honour, his case had already instigated an ongoing national debate about the reform of the law regarding honour crime. When eyes were drawn once again to a Sicilian courtroom, Italian public opinion was already all too alert to the issue of honour 
crime, widely acknowledged not least by many within Sicily as out of step with 1960s Italian society. ${ }^{45}$

Although the issue of honour did of course frame the entire case, it also became clear in the course of the trial how difficult it was to separate certain styles of romantic love from honour itself. The media coverage of the case suggests that the notion that Viola was 'dishonoured' by her kidnap or should have taken honour into account in her decision not to marry Melodia was soundly rejected by popular opinion in Sicily, at least in public. ${ }^{46}$ Even Melodia's own defence team, perhaps in recognition of the popular mood, chose to focus on love rather than honour as a motive. The media was in general agreement in rejecting the vocabulary of sentimentality and romance that usually crept into the coverage of cases of kidnap-elopements because of the ambiguity between love and violence that always lay at the heart of them. ${ }^{47}$ The Sicilian and southern newspapers took particular care to distance themselves from the sentimental interpretation, only using such vocabulary ironically in order to dismiss the connection between kidnap and romance. ${ }^{48}$ However, even in their negative form, certain notions of romantic love were present in the trial and media coverage, and the tension between different styles of love - usually associated with place, or depicted as 'modern' or 'backward' - framed the case. The lack of any sustained engagement with the case in the Catholic media - it was not mentioned in L'Osservatore Romano, and Famiglia Cristiana contained only a brief note in praise of Viola's courage that January - also ensured that discussions of the case were largely framed in terms of emotions rather than morality. 49 
The defence case rested solely on the argument that Melodia had carried out the abduction because of his love for Franca and his desire to marry her, despite her father's opposition. Viola and Melodia had been in a romantic relationship for six months several years earlier but Bernardo Viola insisted that his daughter end the engagement when he found out that Melodia was a convicted thief. Afterwards Melodia emigrated to Germany for work and Viola became engaged to another man in January 1965. In the meantime Melodia had returned to Alcamo and was still obsessed with his ex-girlfriend, threatening her father, her new boyfriend and keeping Viola under surveillance. The defence case painted Bernardo Viola as a tyrannical father who was determined to keep the two lovers apart. In Melodia's words, published as part of a pre-trial interview:

In December 1964, back home from Germany, I was only able to see my exgirlfriend when I passed by the street where she lived, without exchanging any words with her. In these recent times, since I always intended to marry the aforementioned Franca Viola in one way or another, I began again to pass by her house often. Viola did no more than look at me, but did not in fact seem offended by my manner. ${ }^{50}$

Here Melodia was aligning himself with the Sicilian and southern tradition of a strong, secret love forged through glances between a couple. Since Sicilian women did not appear often in public and were seldom unaccompanied, this was often the only way in which feelings of love might be cultivated. ${ }^{51}$ In the absence of any opportunity for the couple to become acquainted, a love forged through glances, and perhaps secret notes, might be felt and experienced as real. ${ }^{52}$ Bernardo Viola's opposition to their original engagement two years earlier added weight to Melodia's (?) case. While this tradition of romantic love was still strong in the 1960s popular consciousness, its roots stretched back to the medieval European tradition of courtly love in which a woman was idealised by a 
male poet and strong feelings of love were sustained despite very little contact with the beloved. ${ }^{53}$ Usually considered in opposition to marriage, the tradition also created space for couples whose families opposed their love to continue in secret and defy their parents. The glance thus became strongly associated with love, longing and, by implication, with female transgression. Melodia's assertion that Viola did not seem opposed to his silent attentions and in fact met his gaze, was, in this context, anything but casual. Melodia's legal team attempted to paint him as another victim of the honour code and the distorted courtship tradition it generated, in which parental control of daughters meant that their suitors had to kidnap them with feigned violence in order to marry them. ${ }^{54}$ In his lawyer Ragusa's summing up, 'Melodia acted out of love and "they want to jail him for twenty-two years for falling in love with a girl"'.55

The defence case rested not only on Melodia's love for Viola but also on her alleged love for him; by implication, then, she was an accomplice rather than a victim. While Melodia's team attempted to portray Viola as a woman in love thwarted by her tyrannical father, she herself, aided by the many journalists covering the trial, put forward her own, competing definition of love. One of the few statements directly attributed to Franca Viola herself was her explanation for refusing the reparatory marriage: 'I will marry the man I love'. ${ }^{56}$ Here she aligned herself with a different definition of love, refusing the sentimental language that surrounded the kidnapping tradition and asserting her right to choose her marriage partner. While her engagement to Antonino Zagari in January 1965 seems to have ended as a result of intimidation by the Melodia camp, Franca Viola married another local man, Giuseppe Ruisi, in 1968. Her parents, in their statements to the media, also aligned themselves with this 
definition of love when they declared their support for their daughter and their desire not to condemn her to an unhappy marriage. ${ }^{57}$ The prosecution's closing statement also rested on this other definition of love.

Franca Viola chose to follow her feelings rather than the path indicated by convenience or the traditions of her town. We should all be convinced that a marriage in these circumstances is an offence to the notion of a marriage governed by feeling. 58

Repeated reference was made in the media to that fact that Viola was 'following her feelings' in her decision not to marry Melodia; love was thus the opposite of Sicilian tradition rather than entwined with it as the sentimental language of the defence team had suggested. ${ }^{59}$ This battle to appropriate the vocabulary of love reflected just how much was bound up in the concepts of romance and feelings; words about emotions could indicate what a woman's place was in a relationship, as well as denoting alliance with either older traditions regarding gender and marriage or a 'new' and modern Sicily. ${ }^{60}$

In the face of a competing definition of love from Franca Viola herself, the fragility of the defence case became clear. While Melodia's lawyers did their best to sentimentalise her kidnap, his case was really driven by honour, a notion which even his own legal team preferred to dismantle rather than uphold in their presentation of the defence case. As his own legal team's depiction of him as a thwarted, tragic lover failed to take hold in the popular imagination, the media began to elaborate their own version of Melodia. To those covering the case he represented the brash, violent and distasteful face both of a certain type of masculinity and of the link between local Sicilian society and the criminality of the mafia (figure 2). Sicilians had historically been constructed by Italian culture as both violent and ruled by their passions. For Baron Von Riedesel, writing in 
1771, Sicilians 'often caused the most violent actions', while for Leopoldo Franchetti almost a century later, it was 'precisely their way of feeling and of seeing that constituted the illness to be cured'. ${ }^{61}$ The national media was thus easily able to fit Melodia into preconceived notions of Sicilian masculinity. Moreover, for some northern journalists, the Sicilian dialect which Melodia and his family spoke was portrayed as unintelligible; a detail which served to emphasise the gulf in understanding they perceived between urban Italy and Sicilian peasant culture. ${ }^{62}$ The coverage in the Bologna based Il Resto del Carlino veered notably close to racism. Sicily's distance to the rest of Italy was also conveyed through both temporal and spatial metaphors; it was at the same time African and medieval. Ferrante Azzali, in his outrage about Viola's treatment while writing about the background to the case in the lead up to the sentencing, repeatedly used the word 'barbaric', reflecting existing prejudices towards Sicily. He also referred to a 'medieval obscurantism, a custom that belongs to the night of time'.63 Sicily was not only distant and different, it was also dark. Reflecting on the trial after the sentencing, he commented savagely on a society that had 'the morality of an African tribe'. ${ }^{64}$ Descriptions of Sicily as dark, backward and African were hardly new, as John Dickie and Nelson Moe have found, and Il Resto Del Carlino exploited these existing prejudices in their trial coverage. ${ }^{65}$

Most other media coverage, while emphasising difference and distance, was less directly racist in tone. Geographical and temporal comparisons did, however, seep into the related debates about honour crime and the need for law reform. Pointing towards the need to remove honour from the legal code, Turin based daily La Stampa carried a detailed interview with the governor of 
Maidstone prison, which emphasised the justice and rationality of the British system, thus aligning itself with northern Europe rather than with the peninsula. La Nazione of Tuscany also made implicit geographical comparisons in an article which asserted that in Tuscany crimes of passion were firmly in the past. ${ }^{66} \mathrm{Here}$, as in Corriere della Sera and La Stampa, the explicit comparisons were temporal; the crimes themselves as well as the law that protected them were both 'ancient' (La Nazione) and 'medieval' (La Stampa, Corriere della Sera and L'Unità), while A. C. Jemolo went even further, declaring in his outrage that article 587, which permitted leniency for so-called crimes of honour, 'brings us back to the time of hordes and tribes' ${ }^{67}$ Such descriptions all too easily mapped contemporary discussions of honour crime onto ways of formulating Sicily and the south as backward in both time and temperament, at least two centuries old by the 1960s. ${ }^{68}$ However, debates in Sicily itself were just as heated, and while some inevitably defended article 587 and proudly hailed honour as a mark of Sicilian difference, the weight of Sicilian opinion fell behind a clear rejection of forced marriage and honour killings. ${ }^{69}$

In Sicily, as elsewhere, the primary focus of the trial coverage was on the 'new' and 'modern' Sicily represented by the Viola family. ${ }^{70}$ Franca's father Bernardo Viola was hailed as the champion by the media. Depicted as a simple and proud peasant man, he exuded honesty and integrity in media photographs and interviews. ${ }^{71}$ Lauded for his unwavering support of Franca Viola, his role, as presented in the press, was at least as great as that of his daughter. It was his decision to involve the law in the case of his daughter's kidnapping, rather than to take matters into his own hands, which ultimately marked him out as a model citizen. By going to the police he had acted rationally and 'in the most civically 
responsible way possible', rather than giving into the violent passions that were apparently so typical of Sicilian men, or doing as 'men of honour' - honour here is associated with the mafia - were expected to do. ${ }^{72}$ Although Melodia's verdict ultimately excluded all charges of mafia association, both the state prosecution and the press coverage cast him as a young mafia boss, with Bernardo Viola in the heroic position of standing up to Sicily's 'honoured society'. ${ }^{73}$ Viola thus countered dangerous masculinity and private violence - associated in the press with both Melodia and Sicily - with measured, responsible fatherhood and civic responsibility. Progressive and principled, while at the same time traditional and not well educated, Bernardo Viola was the perfect representative of the new, modern Sicily that commentators saw emerging in 1966.

While Franca Viola was lauded by the media for her courage and resolution, she remained a more enigmatic figure than the male protagonists. In February 1966 Epoca magazine had published an extensive feature on Alcamo and the Viola family, but despite repeated efforts, they were unable to interview Franca Viola herself. ${ }^{74}$ While Bernardo Viola was himself interviewed, he was reticent about exposing his daughter to the media. Excuses were given and the interview eventually promised was delayed, stalled and finally cancelled. Scarcely visible in court, Franca Viola's testimony was heard privately and northern journalists commented on how Viola was almost completely covered in a red shawl when entering and leaving court; her desire not to be photographed by the press was accentuated by the local cultural restrictions on women appearing in public. ${ }^{75}$ When she did appear in court, descriptions emphasised her modest demeanour as a typically respectable Sicilian girl. Il Mattino's journalist Renato Filizzoli described Viola as 'the girl with the lowered eyes'. ${ }^{76}$ 
Details such as the lowered gaze, the red shawl and the inaccessibility of Viola reinforced the prevailing images of her both as a modest Sicilian woman and a reluctant public figure, as well as, for some journalists, a culturally remote individual. ${ }^{77}$

While the Italian press was saturated with Franca Viola's name and image in December 1966, on closer glance the woman herself seems strangely absent. ${ }^{78}$ The media attention and public shows of political solidarity masked the fact that it was in reality very difficult for her family to continue life in Trapani following the trial. ${ }^{79}$ Having refused all political and media attention in the years following her trial, it was only in 2014 that she publicly accepted the highest honour of the Italian Republic. ${ }^{80}$ Viola was present as slogan and symbol in 1966 - 'the girl who said no', the modest Sicilian and reluctant feminist - but her own motivations, thoughts and attitudes are much more difficult to discern. The few press photographs of her depicted her either as a young innocent girl or an elegant and stylish woman, symbolising innocence and tradition or modern feminism, depending on the context. Il Resto del Carlino even depicted her Madonna style, giving her plight a religious aura of purity and humility. ${ }^{81}$ (figure 3) She was already in 1966 becoming symbolic of something more than herself. What exactly she did symbolise was never entirely clear, however.

Damiano Damiani's 1970 film about the Franca Viola case, The Most Beautiful Wife perhaps captured best the gulf between the symbolic Viola and the real woman. First introduced as modest and poor - her skill at embroidery fitting the stereotype of the traditional Sicilian girl - Francesca quickly began to speak and act like a modern feminist, telling Vito - the Melodia character - that she would not be treated like a possession and would rather remain a spinster than 
marry him. The real Franca Viola, by contrast, was reported to have accepted her marriage to Filippo Melodia as inevitable at the time when she was rescued by the police. ${ }^{82}$ In Damiani's film, Francesca walked to the police station to report the crime alone, facing a crowded town square and threats from Vito himself, with both her family and the police initially unsupportive. While in reality it appeared that Bernardo Viola was as much responsible for the famous 'no' as Franca herself, for Damiani, family was a distraction from the narrative of Francesca as a modern woman who made bold, courageous choices for herself. In endowing the character with the feminist sensibilities much more recognisable to an Italian public in 1970, the historical woman had again been flattened out of her own story. While Franca Viola never gave interviews nor appeared in public until 2014, it is impossible to escape the suspicion that if she had, she might have disappointed those who lauded her as a proto-feminist in the late 1960s.

The gap between Viola as symbol and the real woman, which Damiani's film portrayal made clear, ultimately made it difficult for Italian feminism to engage seriously with her legacy when the movement took off in the 1970s. Although the name was ever-present, sustained engagement with Viola and what she represented for feminists was rare. ${ }^{83}$ The concerns of the various strands of the Italian feminist movement were primarily with the struggles of women in the context of modern, urban society, such as women and work, wages for housework and, increasingly in the 1970s, the campaign to legalise abortion. Ideas and examples from the international feminist movement - notably the United States and France - often set the tone. Nor did feminism have a strong hold in the south, with the exception of in Naples. ${ }^{84}$ When sexual violence did became a major public concern in the late 1970s, it was mobilised by other cases, 
with reparatory marriage and honour crime receiving comparatively little attention from feminist groups. While the nationwide feminist network Unione Donne Italiane (UDI) consistently included reform of the law on honour crime as one of their campaigning issues, it was never a focal concern, unlike divorce, abortion or sexual violence in the broader sense, and it was not until 1981 that the law regarding reparatory marriage was reformed. ${ }^{85}$ The Viola case ultimately became representative more of the south and the perceived culture clash between Sicily and the modern nation than of the broader struggles of Italian feminism.

\section{Conclusion}

The case of Franca Viola forced the Italian public to confront the issue of gender violence and its cultural and social place within the nation. While honour killings were public events in which both victim and perpetrator were usually men, familiar to the point of being a cliché of southern society, kidnapping and forced marriage were usually much more private affairs, resolved within the family rather than by the law. Confronting these issues involved an uneasy confrontation with a region long considered as 'other' and marginal within the nation. However, the case also came at a time when southern Italians were more visible across the nation than before due to the migration waves of the 1950s and 1960s. In confronting the issues at the heart of the Viola case, northern Italians were also coming to terms with what was often seen as the other within their own cities - the southern migrant. 
Emotions were key to how Sicily was represented; it was difficult to separate crimes of honour from crimes of passion in the Italian legal code. Given that Sicily in the 1960s was also associated above all with the mafia, Melodia could be mapped all too easily onto the familiar image of the violent and emotional Sicilian man. However, although Melodia was clearly being tried for a crime associated with honour, the legal and media battle was fought primarily on competing definitions of love: the Sicilian tradition of love through glances usually intertwined with drama and tragedy, or the apparently modern notion of marriage based on choice, equality and companionship. The ambiguity between love and violence in the former style again points to the difficulty of separating emotions from gender violence and honour crime, a challenge reflected in the press coverage. In casting one style as 'backward' and Sicilian and the other as 'modern', Sicily was again associated with brutality and with the past.

The coverage of the trial, and particularly of Melodia himself, slipped into the language of racism and stereotype on a number of occasions, with Sicily being cast in familiar terms as dark, backward, medieval, tribal and African; such terms reflected not only historic prejudice but more urgent concerns about how Italy wished to position itself in the changing world of the 1960s. By means of its northern industrial boom, Italy had managed to transition to a largely urban consumerist society, comparable economically with the rest of Europe. Its southern peripheries were a reminder of the messy and incomplete nature of the rapid social and cultural transition which the nation had undergone in the previous decade, and the constant media refrains of 'modernity' and 'backwardness' reflected these national anxieties. However, even in hailing the progressive elements in Sicilian society, the media failed to fully appreciate the 
gendered and familial nuances of Sicilian society. In turning Franca Viola, whose own words are seldom heard in 1966 or afterwards, into an icon of feminism while rarely engaging with the meaning of her experience - her own subjective experience as a Sicilian woman was largely passed over. Ultimately the various Sicilies created by the Italian media in 1966 - both the 'backward' and the 'modern' ones - are projections of national anxieties and needs and reflected a failed encounter with Sicily itself.

${ }^{1}$ F. Paolo Ferrara, 'Irrompono sparando per rapire una ragazza', Giornale di Sicilia, 27 Dec. 1966, 1.

${ }^{2}$ F. P. Ferrara, 'Alcamo - arrestati quattro rapitori della minorenne', Giornale di Sicilia, 3 Jan. 1966, 1.

${ }^{3}$ On honour and Sicilian society, see Jane Schneider and Peter Schneider, Culture and Political Economy in Western Sicily (New York: Academic Press: 1976), 86-102 and Charlotte Gower Chapman, Milocca: Sicilian Village (London: George Allen \& Unwin, 1973), 38-41. On honour and Mediterranean society see: J. G. Peristiany, ed., Honour and Shame: The Values of Mediterranean Society (Chicago: University of Chicago Press, 1966); Jane Schneider, 'Of Vigilance and Virgins: Honor, Shame and Access to Resources in Mediterranean Societies', Ethnology, 10, 1 (1971), 1-24 and David Gilmore, ed., Honour, Shame and the Unity of Mediterranean (Washington DC: American Anthropological Association, 1987).

${ }^{4}$ Perry Willson, Women in Twentieth Century Italy (London: Palgrave, 2009), 163.

${ }^{5}$ Both Rudolph Bell and Linda Reeder discuss how the honour system in Sicily was challenged by migration and social change from the late nineteenth century onwards. See Linda Reeder, Widows in White: Migration and the Transformation of rural Sicily (Toronto: Toronto University Press, 2003), 68-73 and Rudolph Bell, Fate, Honor, Family and Village: Demographic and Cultural Change in Rural Italy since 1800 (Chicago: University of Chicago Press, 1979), 90-92.

${ }^{6}$ Schneider and Schneider, Festival of the Poor, 211.

${ }^{7}$ In one report, a young Sicilian woman was abducted while walking in public. The couple, who were apparently in love, returned to her family several days later. The case was dropped after 
kidnapper and kidnapped swore their love and intention to marry in front of a magistrate. 'A lieto fine il ratto della vigilia di Natale. Rapita e rapitore si sono giurati "eterno amore"', Giornale della Sicilia, 28 Dec. 1965, 4.

${ }^{8}$ On the custom of elopement in Sicily, see Gower Chapman, Milocca, 94-5. A further example is described in the unpublished memoir of Giovanni Cosa, 'Camillo in Trincea', Taranto, 1939, Archivio Nazionale Diaristico, MP/96.

${ }^{9}$ In the film Girl with a Pistol (Mario Monicelli, 1968), the character Assunta was abducted while walking to the pharmacy with her mother and cousin. Her boyfriend was unsympathetic afterwards, telling her that she had brought it on herself by going out in public. While the film was intended as a comic exaggeration of the honour code, it nevertheless illustrates this mindset. ${ }^{10}$ See Piero Bevilacqua, Breve storia dell'Italia meridionale dall'ottocento a oggi (Rome: Donzelli, 1993), 40-44 and Anton Blok, The Mafia of a Sicilian Village, 1860-1960: A Study of Violent Peasant Entrepreneurs (Oxford: Blackwell, 1974), 94-102.

11 Similar reports were published across Italy on 28 December: 'In nove per rapire una ragazza siciliana', Corriere della Sera, 10 (Milan); f.d. (sic), 'Una diciottenne rapita dall'Alcamo dall'exfidanzato con sette complici', Il Mattino, 11 (Naples); 'Una ragazza e il fratellino rapita da otto giovanastri', Il Resto del Carlino, 2 (Bologna); 'Ragazza e fratellino rapiti da otto giovani', La Stampa, 12 (Turin).

12 Guido Crainz, Storia del miracolo economico, 252; Perry Willson, Women in Twentieth Century Italy, 127. The legal repercussions of the case also receive a very brief treatment in Ernesto De Cristofaro, 'Retorica forense e valori di comunità. Questioni di onore in alcuni processi siciliani' in Francesco Migliorino and Giacomo Pace Gravina, eds., Cultura e tecnica forense tra dimensione siciliana e vocazione europea (Bologna: Il Mulino, 2003), 371-410: 406-7. In addition, Sicilian writer Beatrice Monroy recently published a short literary meditation on the case: Niente ci fu (Molfetta: La Meridiana, 2012).

${ }^{13}$ Guido Crainz, Storia del miracolo economico: Culture, identità, trasformazioni (Rome: Donzelli, 2005) and Paul Ginsborg, A History of Contemporary Italy, 1943-1980 (London: Penguin, 1990), 210-53. 
${ }^{14}$ Barbara Rosenwein asserts that her concept of 'emotional communities' can be used not just to describe a group that shares both values and ways of expressing emotions but also to exclude or label other groups who do not fit: 'Problems and Methods in the History of Emotions' in Passions in Context I (1: 2010), 1-32, here 12-13. Here I use the term 'emotional styles' as coined by Benno Gammerl as a more flexible and fluid adaptation of 'emotional communities', a term perhaps better suited to modern and contemporary society: 'Emotional Styles: Concepts and Challenges', Rethinking History: Special Issue on Emotional Styles, 16,2 (2012), 161-75.

${ }^{15}$ Mark Seymour, 'Emotional arenas: From provincial circus to national courtroom in late nineteenth-century Italy', Rethinking History, 16,2 (2012), 177-97.

${ }^{16}$ Seymour, 'Emotional arenas', 191.

${ }^{17}$ For a historiographical overview of the 'southern question', see John Davis, 'Casting off the "Southern Problem": Or the Peculiarities of the South Reconsidered', in Jane Schneider, ed., Italy's "Southern Question": Orientalism in One Country (Oxford: Oxford University Press, 1998), 205-24. ${ }^{18}$ Emanuela Scarpellini, Material Nation: A Consumer's History of Modern Italy (Oxford, 2011), 127. On the Italian economic miracle in European context, see Tony Judt, Postwar: A History of Europe Since 1945 (London: Penguin, 2010), 324-5.

${ }^{19}$ Scarpellini, Material Nation, 125-75; Crainz, Storia del miracolo economico.

${ }^{20}$ Anna Badino, Tutte a casa? Donne tra migrazione e lavoro nella Torino degli anni sessanta (Rome: Viella, 2008). See also Luisa Tasca, "The "average housewife" in post World War II Italy', in The Journal of Women's History, 16,2 (2004), 92-115 and Willson, Women in Twentieth Century Italy, 117-223.

${ }^{21}$ Willson, Women in Twentieth Century Italy, 117; Aida Ribero, Una questione di libertà: Il femminismo degli anni settanta (Turin: Rosenberg \& Sellier, 1999).

${ }^{22}$ Guido Baglioni, I giovani nella società industriale. Ricerca sociologica condotta in una zona dell'Italia del nord (Milan: Vita e Pensiero, 1962), 118.

${ }^{23}$ On the decline in family size, see Ribero, Una questione di libertà, 73-4 and Willson, Women in Twentieth Century Italy, 125 . On the divorce campaigns see Mark Seymour, Debating Divorce in Italy: Marriage and the Making of Modern Italians, 1860-1974 (London: Palgrave, 2007) and 
Fiamma Lussana, L'Italia del divorzio: La battaglia fra stato, chiesa e gente comune (Rome:

Carocci, 2014).

${ }^{24}$ Ginsborg, A History of Contemporary Italy, 219; Guido Crainz, Storia del miracolo economico,

108. See also: Stefano Gallo, Senza attraversare le frontiere: Le migrazioni interne dall'Unità a oggi

(Rome: Laterza, 2012).

25 Franco Alasia and Danilo Montaldi, eds., Milano, Corea: Inquiry into the Immigrants of the

Economic Miracle (Milan, Feltrinelli: 1960), 45. John Foot, Milan Since the Miracle: City, Culture,

Identity (Oxford, Berg, 2001), 37-59.

26 Goffredo Fofi, L'Immigrazione meridionale a Torino (Milan, 1974), 299.

${ }^{27}$ On structural inequalities between north and south and the Cassa per il Mezzogiorno, see

Ginsborg, Contemporary Italy, 229-39.

${ }^{28}$ Fofi, L'Immigrazione meridionale, 253.

${ }^{29}$ Ibid. 228.

${ }^{30}$ Ibid. 253-5. Another study found southern migrants to Turin more tolerant of honour crime than the Piedmontese but without the regional breakdown. See Valeria Pizzini Gambetta,

'Becoming visible: Did the emancipation of women reach the Sicilian mafia?', in Anna Cento Bull and Adalgisa Giorgio, Speaking out and Silencing. Culture, Society and Politics in Italy in the 1970s (Oxford: Legenda, 2003) 201-11; 203.

${ }^{31}$ Carlo Levi, Cristo si è fermato a Eboli (Turin: Einaudi, 1945); Ernesto De Martino, Morte e pianto rituale nel mondo antico (Turin: Einaudi, 1958) and Sud e magia (Turin: Einaudi, 1959); Rocco Scotellaro, L'Uva puttanella, Contadini del Sud (Rome: Laterza, 1964).

${ }^{32}$ See David Forgacs, Italy's Margins: Social Exclusion and Nation Formation since 1861 (Cambridge: CAMBRIDGE UNIVERSITY PRESS , 2014), 167-73.

${ }^{33}$ Edward C. Banfield, The Moral Basis of a Backward Society, Glencoe: The Free Press, 1958.

${ }^{34}$ On post-unification debates about the south, see Nelson Moe, The View from Vesuvius: Italian Culture and the Southern Question (Berkeley, CA: University of California Press, 2002), 224-50.

${ }^{35}$ See Aida Ribero, Una questione di libertà, 72-5.

36 Ibid. 74-5.

37 Giuseppe Grazzini, 'Sepolta viva: aveva osato entrare in un bar', Epoca, 12 Apr. 1964. 
${ }^{38}$ Inchiesta a Palermo (Turin: Einaudi, 1956).

${ }^{39}$ Danilo Dolci, To Feed the Hungry (London: Mac Gibbon and Kee, 1959).

${ }^{40}$ Lieta Harrison, Le svergognate (Rome: Edizioni di Novissima, 1963).

${ }^{41}$ On Fellini's appreciation of Harrison's study, see Salvatore Ferlita, 'Il tempo delle svergognate', La Repubblica, 28 May 2010.

${ }^{42}$ Lieta Harrison, The Wantons: A Searing Study of the Humiliation of Women in Modern Sicily (London: Ortolan, 1966).

${ }^{43}$ Giovanni Arpino, Un delitto d'onore (Milan: Mondadori, 1960); Divorzio all'Italiana (1961).

${ }^{44}$ Goffered Fofi, Capire con il cinema (Feltrinelli: Milan, 1977), 68. Another negative appraisal included: g.f. (Guido Fink), 'Sedotta e abbandonata' in Cinema Nuovo, Feb/March 1964, 127-8. Leonardo Autera's review in contrast was much more positive: 'Sedotta e abbandonata' in Bianco e Nero, Feb. 1964, 50-3.

${ }^{45}$ Voices raised against honour crime within Sicily were frequent in both Giornale di Sicilia and L'Ora, with Leonardo Sciascia and Robert Ciuni the most vocal. See Roberto Ciuni, 'L'altra Sicilia che non applaude', Giornale di Sicilia, 24 Dec. 1965, 2 and Leonardo Sciasca, 'Perché non possiamo dirci cristiani', L'Ora, 3/4 Jan. 1966, 3.

${ }^{46}$ La cittadinanza di Alcamo solidale con Franca Viola', L'Unità, 16 Dec. 1966, 5; Giorgio Frasca Polara, 'La forza di dire no', L'Unità, 18 Dec. 1966, 13.

${ }^{47}$ See 'Introvabile la ragazza rapita da otto giovanastri', Corriere della Sera, 2 Jan. 1966, 10.

${ }^{48}$ See Mauro de Mauro, 'Franca Viola: È stato così', l'Ora, 12/13 Dec. 1966, 3 and Ettore Serio, 'La difesa ha solo un tasto: ratto d'amore alla siciliana', 17 Dec. 1966, 1 and 20.

49 'Non lo sposerò mai' Famiglia Cristiana, 1Jan. 1967, 9.

50 'Lui', L'Ora, 26/27 Nov. 1966, 2.

${ }^{51}$ Gower Chapman, Milocca, 30-49.

52 The memoirs of Sicilian Maria Lamonica, 'In un piccolo centro di provincia' and Calabrian Saverio Forgione, '... Il mio nome è Saverio' demonstrate the real power of the idea of a love cultivated through glances: Archivio Diaristico Nazionale, MP/03 and MP/T2. 
53 William Reddy, The Making of Romantic Love: Longing and Sexuality in Europe, South Asia and Japan, 900-1200 CE (Chicago: University of Chicago Press, 2012); Howard Bloch, Medieval Misogyny and the Making of Western Romantic Love (Chicago: University of Chicago Press, 1991). 54 'La difesa ha solo un tasto: ratto d'amore alla siciliana', 17 Dec. 1966, 1 and 20.

55 'Il Mafioso è Viola’, Giornale di Sicilia, 16 Dec. 1966, 16.

${ }^{56}$ Ettore Serio, "Gli gridai: Se mio padre non ti denuncia lo faro io", Giornale di Sicilia, 12 Dec. 1966, 1.

${ }^{57}$ G. Impellizzeri, 'Franca Viola non sposerà l'individuo che l'ha rapita', Giornale di Sicilia, 5 Jan. $1966,9$.

${ }^{58}$ Quoted in f.d., 'Chiesti centoquaranta anni per i rapitori di Franca Viola', La Nazione, 15 Dec. $1966,7$.

${ }^{59}$ Emilia Granzotti, 'La “legge del cuore”', Il Resto del Carlino, 19 Dec. 1966, 13; Ferrente Azzali, 'Una sentenza riformatrice', Il Resto del Carlino, 18 Dec. 1966, 13.

60 '”Difendiamo una nuova Sicilia"', Giornale di Sicilia, 14 Dec. 1966, 1.

${ }^{61}$ Quoted in Moe, View from Vesuvius, 59 and 92.

${ }^{62}$ Silvano Villani, 'La difesa chiede attenuanti per i rapitori di Franca Viola', Corriere della Sera, 17 Dec. $1966,7$.

${ }^{63}$ Ferrante Azzali, 'La Sfida di Franca Viola', Il Resto del Carlino, 16 Dec. 1966, 13.

${ }^{64}$ Ferrante Azzali, 'Una sentenza riformatrice', Il Resto del Carlino, 18 Dec. 1966, 15.

${ }^{65}$ See John Dickie, Darkest Italy: The Nation and Stereotypes of the Mezzogiorno (London, Palgrave, 1990) and Moe, The View from Vesuvius.

66 Piero Magi, 'Uccidere all’antica', La Nazione, 5 Jan. 1966, 3.

${ }^{67}$ A. C. Jemolo, 'Non è sbagliato soltanto la legge che rispetta il "delitto d'onore"', La Stampa, 31 Dec. 1966, 7.

${ }^{68}$ In 1854 French journalist Alfred Maury described Turin as 'modern' while Salerno belonged to 'ancient times'. Quoted in Moe, View from Vesuvius, 38.

69 'Sotto accusa l’articolo 587: Contrastanti opinion dei palermitani', Giornale di Sicilia, 9 Jan. $1966,7$. 
${ }^{70}$ See, for example, Ettore Serio, 'Difendiamo una nuova Sicilia', Giornale di Sicilia, 14 Dec., 1 and 'Franca Viola difende il no', Giornale di Sicilia, 8 Dec. 1966, 1.

${ }^{71}$ Serio, 'Difendiamo una nuova Sicilia'.

72 'Mia figlia Franca non sposerà mai l'uomo che l'ha rapita e disonorata', La Stampa, 17 Dec. 1966, 9. See also Guido Guidi, 'Chiesti 23 anni per il giovane che rapì e violentò la ragazza: la sentenza', La Stampa, 16 Dec. 1966, 16.

${ }^{73}$ The mafia charge was repeated across the press: 'Una ragazza si rifiuta di sposare il mafioso che la rapì e la sedusse', Il Resto del Carlino, 9 Dec. 1966, 10; 'P. M. all'attacco al processo Viola', L'Unità, 15 Dec. 1966, 5 (Melodia was referred to as 'il giovane "boss"'); 'Hanno parlato dall'Ora, Corrao e Fileccia - paura dei testi mafia e il coraggio di Bernardo Viola: questi temi degli avvocati di parte civile', Giornale di Sicilia, 14 Dec. 1966, 1 and 16.

74 Pietro Zullino, 'Sfidiamo la mafia per questa ragazza', Epoca, 27 Feb. 1966.

${ }^{75}$ F. D., 'I genitori di Franca Viola trattarono col rapitore della figlia', Corriere della Sera, 12 Dec.

1966, 13; 'Respinta la richiesta di una perizia fisica sulla diciottenne che fu rapita e violentata', $L a$ Stampa, 13 Dec. 1966, 5.

${ }^{76}$ Renato Filizzoli, 'La ragazza dagli occhi bassi', Il Mattino, 20 Dec. 1966, 1.

${ }^{77}$ Silvano Villani, 'La difesa chiede attenuanti per i rapitori di Franca Viola', Corriere della Sera, 17 Dec. 1966, 7.

78 This was also noted in Beatrice Monroy: Niente ci fu (Molfetta: La Meridiana, 2012).

79 'La cittadinanza di Alcamo solidale con Franca Viola', L'Unità, 16 Dec. 1966, 5.

80 'Napolitano premia donna di Alcamo che rifiutò nozze riparatrici', La Repubblica, 8 Mar. 2014: available at http://video.repubblica.it/politica/napolitano-premia-donna-di-alcamo-che-rifiutonozze-riparatrici/158513/157006 (last visited 1 Mar. 2015).

81 'Undici anni al rapitore di Alcamo', 18 Dec. 1966, 1.

${ }^{82}$ Franca Viola was reported to have said to the police on their capture of Filippo Melodia, 'don't shoot, he is already my husband'. Quoted in Ettore Serio, 'Il mafioso è Viola padre che non acconsente alle nozze', Giornale di Sicilia, 16 Dec. 1966, 1.

${ }^{83}$ In both histories of the Italian feminist movement and theoretical analyses of its concerns, Viola is not mentioned: see Aida Ribero, Una questione di libertà and Graziella Parati and Rebecca 
West, Italian Feminist Theory and Practice (Madison: Farley Dickinson University Press, 2002).

Honour is listed as one of the many forms of oppression against women in the 1970 manifesto of the Roman feminist group, Rivolta femminile. See Paola Bono and Sandra Kemp, eds., Italian Feminist Thought: A Reader (Oxford: Basil Blackwell, 1991), 38. Otherwise Italian feminism does not seem to engage with the legacy of Viola, honour crime or reparatory marriage.

${ }^{84}$ On the links between Italian and international feminism, see Maud Anne Bracke, 'Our bodies, ourselves: The transnational connections of 1970s Italian and Roman feminism', Journal of Contemporary History, 50: 3 (2015), 560-80. On feminist groups in Naples, see 'Introduction: Coming from the South', in Bono and Kemps, eds., Italian Feminist Thought: A Reader, 5. ${ }^{85}$ For example, at an UDI conference on the need for law reform regarding adultery, honour crime was discussed in the context of the need for broader reform of family law, specifically regarding adultery and divorce (12 Dec. 1961. UDI archive: busta 2, fascicolo 22). Again, a seminar held by UDI in 1965 on family law reform mentions honour crime as a secondary concern to the law on separation and women and work (UDI archive: busta 3, fascicolo 26), while an open letter to parliament on the proposed large-scale reform of family law, in which honour crime was included in discussions, did not mention it as a priority (UDI archive: busta 5, fascicolo 74). 